\title{
United States Economy \& The Stock Market
}

Harjit K. Arora, Ph.D., (E-mail: arora@lemoyne.edu), Le Moyne College Michael P. Buza, (E-mail: mpbuza@crumetals.com), Crucible Specialty Metals

\begin{abstract}
Is this a new economy? Inflation and interest rates are low. Compared to previous recessions, unemployment rates are also low but productivity is growing at a healthy pace. For the first time since the 1920s stock markets have been falling during the first few months of an economic recovery. The U.S. stockholders wealth has been reduced by approximately $\$ 8.0$ trillion between March 24, 2000 and October 9, 2002. Information technology and telecommunication sectors have lost more than 50 percent of their market value. The U.S. consumer has so far shrugged off the bursting of technology bubble. However, the real estate sector is forming a bubble in some areas now. Of late, the enthusiastic American consumer has shown signs of fatigue in the face of corporate scandals, higher trade deficits and resurfacing of federal deficits. This essay finds that the current bear market is similar to the 1929-1934 bear market in many respects. An important difference between the current market and 1929-1934 period is the participation rate and the presence of defined contribution as well as defined benefit plans.
\end{abstract}

\section{Introduction}

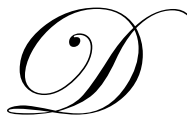

uring the G8 Summit in 1997 in Denver, President Bill Clinton bragged, "America's economy is the healthiest in a generation and the strongest in the world". Since then, the U.S. economy has turned the other way. During the year 2000, it started to show signs of fatigue from the excesses of late 1990s. In the 1980s and 1990s, the stock market's sustained ascent was the central and dominating fact of American history. It has lost all it gained between 1997 and 1999. The Dow Jones Industrial Average Index (DOW) peaked at 11722.98 on January 14, 2000 and the NASDAQ Index at 5046.86 on March 9, 2000. The total market index, Wilshire Index, hit its summit on March 24, 2000, and has shed more than a 1,000 companies since. The stock market has lost more than $\$ 8.0$ trillion dollars in total wealth in the U.S. The DOW closed at 7286.27 , about 38 percent below its all time high and NASDAQ closed at 1114.11, about 78 percent below its March 9, 2000 level on October 9, 2002. However, the unemployment rate has stayed under six percent and the inflation rate has stayed low. The Federal Reserve has cut interest rates 11 times during the year 2001 to help boost capital spending and shore up consumer confidence.

A resilient American economy has shrugged off bursting of the technology bubble with a recession that was shallow and short. American productivity growth remains impressively stronger than it was in the 1970s and 1980s. Recently, however, American consumer and investor confidence has been slipping with rising trade and federal deficits, and increasing unemployment. Unlike the 1990s, the current account deficits are now financing consumer spending and not private sector investment. For the first time since the 1920s, stock market has fallen during the first few months of an economic recovery. There is the speculation of a double dip recession and the Fed cutting rates further this year. Manufacturing sector, which is 17 percent of the total economy, is already showing signs of weakness since August after recovering from an 18 months long downturn since June 1999.

Economic downturns or recessions are not periodic and they differ in duration, intensity, and occurrence. Almost all recessions have resulted from non-economic events such as a war, a sharp increase in oil prices, a major strike, and wage, price or credit controls. Although each business cycle is unique, there are similarities in the sequence of events and circumstances that typically occur over the course of a business cycle. Domestic economic policy, foreign influences, and forces inherent in the manufacturing and domestic construction activities affect each business cycle.

Readers with comments or questions are encouraged to contact the authors via email. 
The objective of this paper is to compare the economic conditions during the previous major bear markets, identify the similarities and differences during these periods, and to find out why the DOW and NASDAQ indices have dropped so low. Section 2 overviews the economic cycles and the stock market. Section 3 reviews stock market crashes and bubble formation. Section 4 gives a brief overview of the stock market's reactions to tragedies in the past. Section 5 lists the Corporate Governance laws passed to date and the recommendations made in June 2002 by the Corporate Accountability and Listing Standards Committee. Section 6, concludes the discussion.

\section{Overview Of Economic Cycles And The Stock Market}

The last 102 years have witnessed nineteen financial markets cycles. In most cases, the bear market was either preceded or followed by a recession. However, four major economic cycles have significantly forced substantial economic change. According to Joseph A. Schumpeter (1912), entrepreneurial innovation is the driver of growth. Schumpeter asserted that industrial expansion is the basic fact of economic growth accompanied by increasing specialization ${ }^{1}$. The economic cycle that started in 1927: IV peaked out in 1929: III ended and continued to be a depression (1929-1933). However, the economic pain continued to be felt till 1939, the beginning of World War II. The other two economic cycles ended in severe recessions (1974-1975 and 1981-1982). The last economic cycle resulted in a shallow recession that started in March 2001, and the GDP grew at negative rates for three quarters. All these three periods of economic prosperity were called the 'New Economy.'

The economic cycle of 1920s got its expansion momentum from the advancement of electrical use and expansion of railroads. This contributed to higher levels of productivity and economic growth. Low inflation, high merger and acquisition activity and deregulation marked the 1920s. Automobile sector was the most profitable sector of the economy ${ }^{2}$. The economic boom and the bull market of the 1920 s ended in a catastrophic collapse of stock market prices on the New York Stock Exchange on October 29, 1929. According to Dornbusch and Fischer, "the Great Depression of 1929-1934 was not caused by the stock market crash because the large falls in output did not occur until two years later ${ }^{3} . " 11,000$ of 25,000 banks of the United States had failed by 1933 due to the banking panic of 1931. With plummeting of consumer confidence, consumer spending declined drastically resulting in a with negative wealth effect. The manufacturing output fell to 54 percent of its 1929 level, and unemployment had risen to 23.6 percent of the work force by 1932 . The U.S. economy was largely agricultural. Imports and exports accounted for a very small part of total GDP.

The mid-1950s to late 1960s is called the "Golden Period" for U.S. economy. During this economic cycle, technology to efficiently mass-produce automobiles became available. Life was good as a series of welfare programs were started after World War II. Inflation as well as unemployment rates were low, and labor productivity in manufacturing was high due to automation of the work place. Technology revolution in the automotive sector also increased U.S. exports and income levels. Petroleum prices quadrupled during October 1973, pushing the U.S. economy into a significant recession during 1974-1975 and ending the economic cycle. Escalating costs of energy drove inflation and unemployment up. As business profits declined and corporations failed to pay dividends to their stockholders, the consumer and investor confidence precipitated. The stock market reacted by selling aggressively ending the bull market of late 1960s and early 1970s. The U.S. labor force productivity declined and unemployment went up. The Federal Reserve Bank lowered interest rates to help businesses and reduce unemployment, but it fueled inflationary pressures. The inflation rate for remainder of 1970s remained very high, and federal budget deficits started to go up.

The U.S. economy experienced a minor slowdown in the early 1980s. However, higher interest rates pushed the economy into a deep recession during 1981-1982. The non-farm unemployment rate rose to 10.8 percent. During the same period, 1981-1983, then President Ronald Reagan gave an across the board tax cut of 25 percent and rose defense spending by 5 percent. The economy got back on its feet quicker this time. An adverse effect of this policy was, federal budget and trade deficits started to grow. A new bull market also started during mid1982. By 1983, the inflation rate dropped to 3 percent and unemployment also started to decrease.

\footnotetext{
${ }^{1}$ Joseph A. Schumpeter, "Theory of Economic Development."

${ }^{2}$ Ravi Batra, "The Great Depression of 1990."

${ }^{3}$ Dornbusch and Fischer, "Macroeconomics."
} 
Consumer confidence increased, and by mid-1980s the economy was healthy again but the federal debt was mounting rapidly. In late August 1987, the economy and the stock market were booming. However, the manufacturing sector was still experiencing very low productivity growth. Inflation and unemployment were hovering between six-to-seven percent per year. High U.S. GDP growth rate of 1987: III coupled with federal budget and trade deficits spooked investors abroad. It triggered a loss of confidence in the U.S. economy, and a big sell off occurred on the New York Stock Exchange on October 19, 1987. The market dropped 508 points in one-day, more than that on the Black Tuesday, October 29, 1929, followed an additional 250 points drop on the next day. Between September and October 1987 real stock prices fell by 13 percent. Total consumer spending (in 1982 dollars) fell at a seasonally adjusted annual rate of 2.1 percent between the third and fourth quarters of 1987. According to Romer's (1990) calculations, consumer spending on durable goods fell at an annual rate of 19 percent between the third and fourth quarters of 1987, with automobiles being particularly hard hit. Between the fourth quarter of 1987 and the first quarter of 1988 total consumer spending rose at an annual rate of 4.4 percent and spending on durables goods rose at an annual rate of 13.7 percent. Whereas the stock prices were very volatile after the crash of 1929 , they stabilized relatively quickly after the crash of $1987^{4}$.

The U.S. economy suffered a shallow recession during 1990-1991 due to corporate restructuring and greater utilization of computers. The information technology that was in the early phase of its innovation got a big boost as it became widely available to the whole economy through computers. The second half of the decade of 1990s popularized computers and Internet access and increased labor productivity at a very rapid pace. Business profits increased and unemployment and inflation rates dropped significantly. With the new millennium approaching, the government at all levels and the private sector started to get ready for $\mathrm{Y} 2 \mathrm{~K}$ regulation compliance. This activity gave a big boost to information technology. In addition, unemployment decreased to 3.9 percent in 1999, below the full-employment level and increased productivity reduced the inflation level to below 2 percent in 1998.

The stock market took off in 1995 as consumer confidence soared. The federal budget posted its first surplus in 30 years starting in fiscal year 1998. There have never been two consecutive decades of high-sustained stock performance like the 1980s and 1990s. Average returns approaching well over 10 percent have only occurred during the 1920s and 1950s prior to 1982-1999 bull market. When adjusted for inflation, the $1920 \mathrm{~s}$ and $1950 \mathrm{~s}^{5}$ and the second half of the 1990s were the most stellar periods for stock returns. All of these periods had similar macroeconomic conditions, i.e., low inflation, high employment, and high labor productivity.

The bull market that started in August 1982 came to a halt in early 2000. It started to decline at a faster pace during the years 2001 and 2002. According to Blumenthal (2002), out of 121 million the U.S. population in 1929 only about 1.5 million to 3.0 million owned stocks ${ }^{6}$. Presently, more than 50 percent of the U.S. population participates in the stock market directly or indirectly. Besides the financial markets, other forces also created a slow down in the U.S. economy. During the late 1990s, monitoring the wealth effect became a popular practice. Most economists assumed that consumers spent about 4 percent of their stock market gains. However, it has been difficult to find any negative effect on consumer spending from the severe decline in stock market over the past two years. According to Wysocki, Jr. (2002), gains from housing sector have mitigated the loss of wealth from the stock market. "An International Monetary Fund study concluded that between January 2000 and October 2001, the downturn in equities lowered consumer spending by 1.9 percentage points. However, this was almost offset by a 1.6 percent point gain from spending by homeowners out of the building in the value of their homes ${ }^{7}$." Temin (1976) also finds fairly small wealth effect of the stock market in 1929.

But the Fed perceived inflation on the horizon due to the wealth effect of the excellent performance of the stock market during 1995-1999 and over optimism of Americans. The Fed increased interest rates six times during mid-1999 to mid-2000 because of the threat of inflation. These increases further contributed to the decline in U.S. economy. The business investments for new technology-related capital also slowed dramatically as the overhang from Y2K compliance passed. An increase of approximately 100 percent in energy prices since the year 2000 also raised the cost of production thus contributing to the slow down.

\footnotetext{
${ }^{4}$ Romer, "The Great Crash and the Onset of the Great Depression."

${ }^{5}$ Harry Dent, "The Roaring 2000s", pp.28.

${ }^{6}$ Blumenthal, "Six Days in October: The Stock Market Crash of 1929."

${ }^{7}$ Wysocki. Jr., "Forget the Wealth Effect: Income Drives Consumer Spending."
} 
Manufacturing and technology sectors were the hardest hit. U.S. manufacturing declined for 18 months before recovering in early 2002. During the 1996-1999 period, technology spending grew at a much faster pace than the 1993-1995 period to ensure that private and public sectors were compliant with Y2K regulations. Still the rate of inflation stayed below 2.5 percent throughout this period. The unemployment rate has recently climbed to 5.9 percent from 3.9 percent in 1999. Consumer sentiment as measured by the 'Michigan Consumer Sentiment Index' has declined to its lowest levels since 1993 and retail sales are also getting softer in 2002 compared to the past six years.

The attack of September 11, 2001, destroyed the Twin Towers of World Trade Center in New York City's financial district. According to New York States' estimates, this resulted in a financial loss of approximately $\$ 95$ billion and 146,000 jobs in New York City alone. As the U.S. economy started to recover, later in the fall of 2001, Enron, an energy conglomerate announced bankruptcy, followed by Global Crossing, Adelphia, Worldcom, and many others due to fraudulent accounting practices. Most of these companies had Arthur Anderson as their accounting and consulting firm. Corporate frauds and scandals have eroded investor confidence and have significantly slowed down the recovery process.

\section{Section 3: Stock Market Crashes And Bubble Formation}

Speculation, according to the McGraw-Hill Dictionary of Modern Economics, is "the act of knowingly assuming above-average risks with the hope of gaining above-average returns on a business or financial transaction." As Charles Kindleberger (2000) wrote in his book Manias, Panics, and Crashes: A History of Financial Crisis, "Speculation tends to detach itself from really valuable objects and turns to delusive ones. A larger and larger group of people seeks to become rich without a real understanding of the processes involved. Not surprisingly, swindlers and catchpenny schemes flourish ${ }^{8}$." Many bubbles, such as the 1840s railway mania in England and the Wall Street boom of the 1920s were associated with exciting new inventions that created exaggerated hopes of profits. In the 1920s there were radio, talking pictures and passenger aircraft. Bubbles are usually associated with periods of prosperity, when the future seems bright, investors are cocky, and there is easy access to money and credit ${ }^{9}$.

Consumer and investor confidence and economic growth create a bull market and the excessive pessimism that follows this exuberance creates a bear market. Since 1900, the United States Economy has experienced 19 bull markets and 20 bear markets. On average, the DJIA gained 152.38 percent during a bull market with largest gains during August 24, 1921 - September 3, 1929 (496.5 percent); October 11, 1990 - January 14, 2000 (395.7 percent); June 13, 1949 - December 13, 1961 (354.8 percent); and August 12, 1982 - August 25, 1987 (250.4 percent). The last four bull markets have lasted for 60.6 months as compared to the previous 15 bull markets that lasted for 35.64 month on average ${ }^{10}$.

The average loss during the bear markets is 37.25 percent in last 102 years. 15 of the 20 bear markets happened before 1975 and the losses were also pronounced during these bear markets. DJIA suffered its largest losses during the bear markets of September 3, 1929 - July 8, 1932 (89.19 percent); February 5, 1934 - July 26, 1934 (52.20 percent); and January 19, 1906 - November 15, 1907 (48.54 percent). Bear markets since 1976 have averaged loss of 27.58 percent. Bear market durations have been reduced from 25.89 months for the first 15 bear markets to 14.28 months for the last 5 bear markets ${ }^{11}$.

As the economy gains expansionary momentum, several new businesses start to help fuel expansion. The financial needs of these new enterprises alter the business place and the capital markets. The market for industrial securities, which first emerged in the 1880s, came of age in the 1920s, boomed as both old and new corporations issued equities to finance new plant and equipment. As the Fed doubled interest rates in late March 1929 to discourage investors, corporations such as Bethlehem Steel, Standard Oil Company of New Jersey, Chrysler Corporation, General Motors, and Cities Service Company - an energy company, started to lend money to speculators and new

\footnotetext{
${ }^{8}$ Kindleberger, "Manias, Panics, and Crashes: A History of Financial Crisis."

${ }^{9}$ Cassidy, "DOT.CON the Greatest Story ever Sold," pp. 26.

${ }^{10}$ Wall Street Journal, October 16, 2002

${ }^{11}$ Data for this section is from Crandall, Pierce \& Company. By Permission.
} 
investors. New investors had seen stock market increase by 48 percent in 1928 and believed that market would only go up but they lacked experience in buying stocks and monitoring firms. Brokers were also making loans on margin and by October 1929, the loans had reached $\$ 8.5$ billion. But only an estimated 600,000 people had margin accounts in $1929^{12}$.

According to Cassidy, during 1929, automobile companies and suppliers ranked among the most heavily traded stocks. RCA represented new technology and was also a dominant stock. RCA's sales were growing by 50 percent each year. Its prospects, which looked excellent as the economy recovered, were reaffirmed by the release of the company's 1927 annual report in early March 1928. RCA did not pay dividends, however, in the belief that the business will continue to thrive and the price of its stock would increase in the hope of dividends in the distant future. Blumenthal (2002) writes, "With so many people trying to buy stock, Radio's stock price made a stunning jump, climbing more than $\$ 20$ in just two days, to $\$ 120.50$ a share ${ }^{13}$." Many other prominent companies that did not pay dividends caught the public's attention, too. These included Radio-Keith-Orpheum, the Aluminum Company of America, and the United Aircraft and Transport Corporation. Like RCA, these firms used new, developing technologies. The proportion of firms not paying dividends was also high among public utility holding companies. These included the Commonwealth and Southern Corporation, Electric Bond and Share, and the North American Company. The electric utility industry was undergoing a remarkable growth because of transformation in the 1920s. Consolidation and expansion had given these firms great economies of scale in production and transmission. This was another frontier industry with potentially high but uncertain returns. The boom in utilities far outstripped industrials, while the relatively stable, established railroads languished ${ }^{14}$.

The rise of stocks like America Online, Netscape, and Yahoo was part of a broader phenomenon. In the first four-month of 1996 alone, American households deposited about $\$ 100$ billion in stock mutual funds. As recently as in 1990, these funds had taken in just $\$ 12$ billion during the entire year. Between the beginning of 1995 and May of 1996, the DOW climbed to 5,643.2, a rise of 45 percent and NASDAQ rose by about 65 percent to 1,243.43. By the summer of 1996, about 800,000 Americans had online trading accounts. 1998 was the year when the Internet stocks with investors of all types gained momentum. Internet stocks shot up in late October and early November 1998. On March 9, 2000, NASDAQ closed at 5,046.86. It took only four months for NASDAQ to move from 3,000 to 5,000. Until the middle of 1990s the big Wall Street firms dominated trading in NASDAQ stocks. But by early 1999, there were more than sixty day-trading firms, with almost 300 offices, across the country. By the start of 1999, day trading accounted for about 15 percent of the total trading volume on the NASDAQ ${ }^{15}$.

The U.S. economy started to slow down during the second half of the year 2000, and the rest of the world followed. The U.S. and the world financial markets posted double-digit negative returns for years 2000 and 2001. DJIA climbed to 11,723 during the first few days of the new millennium and then started to decline. The NASDAQ Index reached 5,047 before slipping on March 9, 2000. As of October 9, 2002, both the DJIA and NASDAQ closed at 7286 and 1114 respectively. Nikkei 225 is at its nineteen-year low level and other major world financial markets are also posting double-digit negative returns. Zeira (1999) presents an explanation on stock markets' crashes of 1929 and 1987 based on informational dynamics and suggests two possible triggers to booms and crashes, namely rapid technical progress and reduction of entry costs to the market:

Both the 20's and the 80's have been expansionary periods in the U.S. Between the years 1921 and 1929 GDP has grown at an average rate of $4.8 \%$ a year and output per capita has grown at an average rate of $3.3 \%$. These are very high rates of growth relative to other periods in American history. The 80's have also been a period of expansion after a short recession in 1981-1982. Between the years 1982 and 1989 GDP has grown at an average rate of $3.7 \%$ in what was considered to be the longest post-war expansion. The two American episodes are also characterized by large entry of new investors to the stock market.

\footnotetext{
${ }^{12}$ Blumenthal, "Six Days in October: The Stock Market Crash of 1929."

${ }^{13}$ Blumenthal, "Six Days in October: The Stock Market Crash of 1929." Pp. 26

${ }^{14}$ Cassidy, "DOT.CON the Greatest Story Ever Sold."

${ }^{15}$ Cassidy, "DOT.CON the Greatest Story Ever Sold."
} 
The second half of the 1990s resembles 1920s and 1980s very much. Extending Zeira's hypothesis of productivity growth and liberalization of financial markets to the year 2000-2001, one finds that the productivity growth averaged 4.27 percent between 1995 and 2000. Beginning in 1995, access to the stock market through online brokerage firms became very inexpensive and easy. Trading in technology stocks without checking the fundamentals of the firm became common among most investors as access to online trading expanded. The mass psychology that every dot-com will be profitable in the future intensified the boom in the stock market. As dot-coms' started to suffer from the high cost of infrastructure, operations, absence of present or future profits, and started to declare bankruptcies beginning in the year 2000, the same mass psychology that created a boom during the 19951999 period, created a crash in the NASDAQ.

The consumer and housing sectors that had held up well until now have, however, started to lose steam recently. During years 2000 and 2001, people had moved money into energy and health care company stocks. However, the corporate scandals of Enron, Global Crossing, World Com, Imclone, Bristol-Meyers, etc., have made people flock to the real estate sector for security. The increase in unemployment has dampened the consumer sentiment. Layoff announcements are still coming and recovery from the recent recession that started during March 2001 is very anemic.

Stock market crashes often happen in news vacuum. There was no particularly bad news in October 1929, October 1987 and January-March 2000 either, but all three episodes were preceded by periods of increased volatility. In Keynes's view, the source of the Great Depression was "not in the high level of investment which was proceeding up to the spring of 1929, but in the subsequent cessation of this investment ${ }^{16}$." The investment by corporations in new technology has also dried up preceding this current bear market. Investment in manufacturing had already been suffering since mid-1999.

Not all stocks participated in the boom of 1928-1929. Railroad stocks were excluded from the boom, while utilities were the favorites of speculators. The boom of late 1990s has created a dynamic explosion of productivity growth in the durable manufacturing sector, both in the manufacturing of computers and semiconductors and of other types of durables. However, the New Economy has meant little to 88 percent of the economy outside of durable manufacturing. The trend of growth in multifactor productivity has actually decelerated, despite a massive investment boom in computers and related equipment ${ }^{17}$.

\section{Impact Of The Tragedies On The U.S. Economy}

Since 1940, there have been 33 crisis events - 20 during the bull markets and 13 during the bear markets ${ }^{18}$. After crisis events the stock market returns to its underlying strengths or weaknesses. In bull markets, crisis events run their course and the market continues to advance whereas these events exacerbate the downturn in bear markets and the bear markets continue. On average the market had gained $44.9 \%$ by the end of the bull market whereas it lost 23.6 by the end of the bear market. Recovery period during the bull markets is shorter than the bear markets. It took only nine days on average during the bull market and fifteen days during the bear markets to get back to market close before the crisis event.

The terrorist attack on the World Trade Center and the Pentagon on September 11, 2001, left the United States economy paralyzed for a few days and has slowed the recovery from the shallow recession. This attack came at a very fragile moment in the economic cycle and brought economic life in America to a halt for at least a week. The sectors that are affected adversely and acutely are Airlines, Insurance, Retail, Tourism and Hospitality industry.

\footnotetext{
${ }^{16}$ Delong, "The "New Economy," Structural Change, and Macroeconomic Outcomes".

${ }^{17}$ Gordon, "Does the "New Economy" measure up to the Great Inventions of the Past?"

${ }^{18}$ France-German Occupation (1940), Pearl Harbor Attacked (1941), Truman Upsets Dewey for Presidency (1948), President Eisenhower - Heart Attack (1957), Suez Canal - Crisis (1956), Sputnik I (1957), Bay of Pigs (1961), The Cuban Missile Crisis (1962), John F. Kennedy Assassination (1963), The Six Day War (1967), The Tet Offensive (1968), Kent State demonstrations \& Shooting (1970), Watergate (1972), Arab Oil Embargo (1973), President Nixon Resigns (1974), Saigon Falls (1975), Iran Hostage Crisis (1979), Three Mile Island - Nuclear Accident (1979), Hunt Brothers Silver Crisis (1980), Iraq Invades Iran - War (1980), President Reagan - shot (1981), Falkland Islands War (1982), Grenda Invasion (1983), Chernobyl - Nuclear Accident (1986), Iraq Attacks USS STARK (1987), U.S. Invades Panama (1989), Iraq Invades Kuwait (1990), World Trade Center - Bombed (1993), Asian Currency Crisis (1997), U.S. Embassies in Africa - Bombed (1998), Bush - Gore Election Crisis (2000), Terrorist Attack on USS COLE (2000), Terrorist Attack on WTC \& Pentagon (2001). By permission. Crandall, Pierce \& Company.
} 
Financial markets are the first to respond to any changes in the economic activity. A check of six major events in the U.S. history prior to September 11, 2001, since 1898 shows that the DOW, a U.S. market benchmark, falls immediately days after a history making even ${ }^{19}$ but typically rebounds within six months. According to Gibbons Burke of MarketHistory.com, on average the stock market indices were down by 3.0 percent a week later and 1.6 percent a month later. During all other earlier incidents, except September 11, 2001, DJIA was up 11.3 percent six-months later, up by 18.4 percent a year later, and 50.4 percent, three-years later.

However the current situation is different. The major U.S. indices are down a year after the attack of September 11, 2001. The DOW is more than 17 percent down and the NASDAQ is down by more than 33 percent. The Nikkei 225 has declined by 13 percent since last September ${ }^{20}$. The major difference between the earlier tragedies and September 11, 2001, is the economic health of the United States and the world economies. The major world economies and the U.S. were in a recession before the attack on the Twin Towers and the Pentagon. Also, a slew of corporate scandals have shattered investor confidence in the stock markets.

\section{Corporate Governance}

Actions of a few of the United States corporations have disrupted the lives of hundreds of investors and shattered dreams of retirement for many even though the U.S. has the most advanced system of corporate governance. A report by CNBC on Business Center estimates cost to the Wall Street from the corporate scandals and the conflict in the research and investment banking has reached $\$ 2$ billion by October 2002. "Up until the 1930s, corporate governance was not regarded as a federal responsibility and there were no requirements about how the corporation should be governed" according to John Steele Gordon. But because of the steep decline in the stock market between 1930 and 1932, the Banking and Currency Committee of the United States held series of hearings on corporate governance. Blumenthal writes ${ }^{21}$ :

For months, the committee uncovered one grotesque example of greed, abuse, and insider manipulation after another. It exposed how syndicates or pools bid up stock prices; how financial reporters were bribed; the enormously high salaries and bonuses paid to top executives; the special stock deals given to wealthy or influential people...National City company...had lent one hundred top officers more than \$2 million after the crash to help them keep their stocks. Almost none of that money was repaid...Mr. Mitchell (Chair of National City Bank) also admitted that he had sold 18,300 shares of National City to his wife after the crash. The reason? So he could show a loss on the sale that would help him avoid paying taxes...Albert Wiggin (Chair of Chase Bank) had retired at the end of $1932 \ldots$ was quietly granted $\$ 100,000$ a year for life at a time when retirement payments were rare and many people were hungry and out of work.

The federal government bolstered corporate governance and disclosure and by 1933, 1,157 companies listed on the NYSE distributed annual reports. In 1934, the federal government under the Securities Exchange Act of 1934 established the Securities and Exchange Commission with authority over all U.S. stock exchanges ${ }^{22}$. SEC required all companies listed on the NYSE to file disclosures. By 1947, 93 percent of the 1,032 active U.S. companies were publishing earnings quarterly or semiannually, in addition to annual reports ${ }^{23}$.

Since the formation of the SEC the issue of corporate governance has arisen numerous times. During the 1950s, the SEC recommended NYSE listed companies to include at least 2 outside directors and NYSE established a policy to discourage securities transactions between a listed company and its officers and directors; and during 1970s, increased the number of outside directors to 3 and required companies to have outside audit committee. During 1984, the NYSE appointed a committee to review voting-rights issues; and the SEC prohibited disenfranchise-

\footnotetext{
${ }^{19}$ Events listed are: sinking of the U.S. battleship Maine (2/15/1898); sinking of the passenger ship, the Lusitania (5/7/1915); attack on Pearl Harbor (12/7/1941); invasion of Kuwait (8/2/1990), bombing of the World Trade Center (2/26/1993); and bombing of Federal Offices in Oklahoma (4/19/1995). MarketHistory.com.

${ }^{20}$ Global Market declines, year to date, at the end of August 2002 are: Xetra Dax (-34.1\%), Paris CAC-40 (-32.4\%), FTSE 100 (-22.8\%), DJIA ($17.1 \%)$, HangSeng (-14.1\%), Nikkei 225 (-12.6\%). Wall Street Journal, August 5, 2002.

${ }^{21}$ Blumenthal, "Six Days in October: The Stock Market Crash of 1929," pp. 138-141.

${ }^{22}$ Prior to 1934, the NYSE was the sole regulator for the stock market.

${ }^{23}$ Gross, "Tried \& True".
} 
ment of existing stockholders in 1988. In 1999, the NYSE required domestic listed companies to have at least three independent directors on their audit committee and established rules for their independence and financial expertise ${ }^{24}$.

Recent accounting irregularities have come to light as a result of companies like Enron, Global Crossing, and WorldCom filing for bankruptcy and several others corporations indicted on their accounting practices. During the same period, unemployment started to rise and the stock market went into steep selling. One of the major problems is stock options and the absence of clear guidelines whether to expense them or not. At the beginning of 2002, the NYSE formed a committee of its members, co-chaired by Leon Panetta, Gerald Levin, and H. Carl McCall to make recommendation to enhance the accountability of its 2,800 listed companies and to help restore investor trust and confidence. The Corporate Accountability and Listing Standards Committee released its recommendations for public comments in June 2002. Appendix A lists the recommendations made by the committee. The committee also required top 1,000 NYSE companies to sign disclosures requiring the Chief Executive Officers and Chief Financial Officers to attest to the earnings of their companies and take responsibility for those earnings by August 15, 2002. Issues regarding expensing of stock options are still unresolved as it is difficult to put value on stock options. Some of the companies have declared that they will expense stock options whereas the technology companies do not like the concept of expensing stock options.

\section{Conclusion}

Technological innovations, productivity increases, and the economic growth give confidence and optimism of a prosperous era to the market participants. These periods often are called 'new economy'. According to Romer, "the 'new economy' is not the inevitable result of structural changes, globalization, or the information revolution; instead, it has emerged because we have had a steadier hand on the macroeconomic tiller in recent years than in the years before ${ }^{25}$." The New Economy created by the post-1995 acceleration in the rate of technical change in information technology together with the development of the Internet, has increased productivity in the manufacturing durable goods sector and has held down inflation.

Bull and bear markets have many similarities. Booms in the economy generate bull markets and many new investors who had never bought stock before enter at the top of the bull market enhancing the bubble formation. Rising stock prices in the post-1995 period created a lot of wealth for Americans. In 1983, the wealthiest 1 percent of the households in America owned 90 percent of all stocks. Fifteen years later, in 1998, almost half of American households owned stocks, either through individual shareholdings or through mutual funds in their retirement accounts. Between 1983 and 1998, the share of American households with some type of retirement savings account rose from 11 percent to 23 percent. During the same period, the hourly wage hardly grew at all for production workers, especially unskilled workers. The sharp decline in the stock market and a loss of approximately, $\$ 8.0$ trillion dollars in stock market wealth has not slowed the American consumer. Consumer spending has increased by 6.7 percent during the past one year.

The Bush government gave a tax cut during 2001 and the Fed has decreased interest rates 11 times during the year 2001 to put the economy back on the recovery path. The terrorist attack of September11, 2001, affected the markets temporarily. However, corporate scandals and a wave of major bankruptcies and increasing unemployment continue to affect the stock market. Currently, the recovery is slow in the U.S. economy, but is better than many other developed nations.

\footnotetext{
24 "Your Market" Straight Talk fro Investors, NYSE.

${ }^{25}$ Romer, "Changes in Business Cycles: Evidence and Explanations"
} 


\section{References}

1. $\quad$ Batra, Ravi, (1987), The Great Depression of 1990 Simon \& Schuster, New York.

2. Blumenthal, Karen, (2002), Six Days in October: The Stock Market Crash of 1929, A Wall Street Journal Book, Atheneum Books for Young Readers, New York.

3. Bureau of Labor Statistics, http://www.stats.bls.gov "Table 6: Manufacturing: Productivity and Related Measures", 1950-99.

4. Cassidy, John, (2002), DOT.CON The Greatest Story Ever Sold, Crandall, Pierce and Company, Libertyville, IL.

5. Delong, J. Bradford, (2001), "The 'New Economy', Structural Change, and Macroeconomic Outcomes", http://econ161.berkeley.edu/Econ_Articles/Jaffe/new_macro_worldlink.html.

6. $\quad$ Dent, Jr., Harry S., (1993), The Great Boom Ahead, Hyperion.

7. $\quad$ Dent, Jr., Harry S., (1999), The Roaring 2000s, Simon \& Schuster, New York.

8. Dornbusch, Rudiger, and Stanley Fischer, (1984), Macroeconomcs, $3^{\text {rd }}$ edition, New York: McGraw Hill.

9. Gibbons, Burke, http://www.MarketHistory.com.

10. Gordon, Robert J., (2000), "Does the 'New Economy' Measure up to the Great Inventions of the Past?" Journal of Economic Perspectives, vol. 14, number 4, pp. 49-74.

11. Gross, Daniel, (2002) Tried \& True, Your Market, New York Stock Exchange.

12. Kindleberger, Charles P. (2000), Manias, Panics, and Crashes: A History of Financial Crisis, Fourth Edition, Wiley.

13. Romer, Christina D. (1990), "The Great Crash and the Onset of the Great Depresion", Quarterly Journal of Economics, vol. 105, Issue 3, pp. 597-624.

14. Romer, Christina D. (1999), "Changes in Business Cycles: Evidence and Explanations", Journal of Economic Prospective, vol. 13, number 2, pp. 23-44.

15. Schumpeter, Joseph A., "Stability and Progress", Notable Selections in Economics, edited by Belay Seyoum and Rebecca Abraham, Dushkin McGraw-Hill, 283-290, 2000.

16. Wall Street Journal, (Au. 13, 2001), "Soon, the Big Three Won't Be, as Foreigners Make Inroads in U.S.".

17. Wall Street Journal, (Au. 5, 2002), "False Bottom? Stocks May Decline Further".

18. Wall Street Journal, (Au. 5, 2002), "Forget the Wealth Effect: Income Drives Consumer Spending".

19. Wall Street Journal, (Sept. 4, 2002), "Made in Japan: U.S. Stocks Fall Again”. 


\section{Appendix}

The Corporate Accountability and Listing Standards Committee released its recommendations for public comment in June 2002:

- $\quad$ Expand the role and authority of independent directors and board audit committees.

- Mandate that shareholders vote on all equity-based compensation plans, including stock-options plans.

- $\quad$ Require audit, nominating the compensation committee to consist solely of independent directors, with a requirement that the chair of the audit committee have accounting of financial management experience.

- Tighten the definition of an independent director, including a five-year cooling-off period for former employees, independent auditors and others.

- $\quad$ Mandate that directors' fee represent the sole compensation that audit-committee members receive from the listed company, and that an audit-committee member associated with a large shareholder (one owing 20 percent or more of the listed company's equity) may not vote in audit-committee proceedings.

- Grant the audit committee sole authority to hire and fire independent auditors and approve any significant non-audit work by the auditors.

- $\quad$ Require CEOs of NYSE-listed companies to attest to the accuracy, completeness and understandability of information provided to investors.

- $\quad$ Mandate that listed companies adopt and publish corporate-governance guidelines and a code of business conduct and ethics.

- $\quad$ Establish an NYSE Directors' Education Institute to assist directors in their responsibilities.

- $\quad$ Allow the NYSE to impose additional penalties, including public reprimand letters, in addition to suspension and delisting.

- $\quad$ Require non-U.S. issuers to disclose how their practices differ from NYSE rules and procedures.

Other Proposals invite Congress and the SEC to:

- $\quad$ Establish a new private-sector organization, funded separately from the accounting industry itself, to monitor and govern public accountants.

- $\quad$ Evaluate the impact of fair disclosure regulation on earnings guidance and to consider reforms.

- $\quad$ Allocate additional resources to the SEC to increase the agency's monitoring and enforcement activities.

- $\quad$ Prohibit relationships between independent auditors and their clients that would affect the fairness and objectivity of audits.

- $\quad$ Permanently bar officers and directors of public companies from holding office again after violating their duties to shareholders.

- $\quad$ Exercise more active oversight of the Financial Accounting Standards Board (FASB) to improve the quality of GAAP (generally accepted accounting principles) and the speed of FASB actions.

- Require companies to report GAAP-based financial information before any reference to "pro-forma" or "adjusted" financial information.

- Improve management's discussion, analysis, and disclosure of financial conditions.

- $\quad$ Require the prompt disclosure of insider transactions.

Source: "Your Market" Straight Talk for Investors, NYSE 